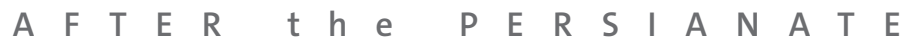

\title{
Indian Friends, Iranian Selves, Persianate Modern
}

\author{
Mana Kia
}

It is better for a man to be without a brother than without a friend. When a sage was asked whether it was better to have a friend or a brother, he said that a brother who is also a friend is best.

— Eleventh-century nasīhatnāmah (advice literature), 'Unșur al-Ma'ālī, Qābūsnāmah the mid-nineteenth century, a Persianate self defined itself in situ, through social interaction with the world. ${ }^{1}$ In basic texts of Persian education, an individual was legible according to moral substance made manifest in proper conduct, which required education to refine perception for the purposes of ethical self-cultivation. ${ }^{2}$ Friendship was instrumental in such efforts. As a truth-telling interlocutor, the ethical friend provided companionship, a relationship understood to assist the individual in sharpening his perception. This in turn helped him fashion a more ethical self, to see what he must do, to do it (in the context of social interaction), and to thereby refine his character. Throughout the late nineteenth century, the role of Persianate friendship remained instrumental in fashioning modern Iranian selves, the delineation of which reveals the temporal and regional continuities inhering in the Persianate modern.

In Sa'dì's Gulistān, a prose primer that any educated Persian would read, the friend is instrumental in the narrator's transformation and his ability to compose a text that was seen as the exemplar of ethics and aesthetics. The Gulistān provided a vision of how to be in the world that traveled into other texts, genres, and oral exchanges. ${ }^{3}$ In the preface, Sa dì-as-narrator describes the conditions under which he composed the Gulistān, beginning with a decision to "withdraw into isolation from the world" as a result of contemplating the regrets of his "wasted life." He then has a visit from an intimate friend. The friend becomes wounded at Sa'dî's refusal to engage with him because of his vow of silence and refuses to accept this decision. The friend reminds Sa'di that "it is well-known that to hurt one's friends $[d \bar{u} s t \bar{a} n]$ is ignorance and to atone for a broken oath is easy" (6). To violate the precepts of friendship is a sign of ignorance and thus a lack of virtue, the gravity of which makes the great offense of violating an oath

This article benefited from conversations and comments at the conference "After the Persianate: Cultural Heritage and National Transformation in Modern Iran and India" held at the University of Oklahoma in March 2014. Discussions with Partha Chatterjee, David Lelyveld, and Daniel Sheffield helped me work out some of these issues. Catherine Ambler, Gil Anidjar, Eric Beverley, and Afshin Marashi thoughtfully commented on earlier drafts. Any shortcomings remain my own.

1. Najmabadi's recent work Professing Selves challenges the triumph of "a psychic interiorized self" (9) or "interiorized deep self in contemporary Euro-American societies" in modern and even contemporary Iran (276). Instead, she outlines "a networked self-in-conduct" (277).
2. Moral substance is the possession of virtues, which are dependent on ethical enactment and embodiment for their realization. I outline the nature of this self in my manuscript in progress, "Sensibilities of Belonging: Transregional Persianate Communities before Nationalism."

3. For more on this text and its role in an eighteenth-century Persianate context, see Kia, "Adab as Literary Form and Social Conduct."

4. Sa'dī, The Gulistan (Rose Garden), 5. The verse that follows declares, "He who sits in a corner, his tongue cut out, deaf and mute [Quran 2:18] / Is better than one whose tongue is not under control (andar hukm)" (ibid.). Italics indicate an Arabic phrase. 
seem slight by contrast. The friend then explicitly makes speech, as the vehicle of intercourse with the world, the basis for realization of individual virtue:

What is the tongue in the mouth, $\mathrm{O}$ wise one? It is the key to the door of the treasure house of the skilled

When the door is shut how can anyone know If he is a seller of jewels or of junk?

This appeal persuades Sa'dī, who "did not consider it virtuous/manly [murūvat] to refrain from conversing, for he [the friend] was an agreeable and sincere friend [yār-i muvāfiq būd va muh̄̄bb-i sādiq]" (ibid.) The friends then spend the night talking and walking through the garden of another friend at the height of spring, amid the lushness of its beauty.

This experience of the embodied virtue of friendship, set in the ideal space of physical beauty and amicable sociality, inspires the narrator to write the Gulistān. The very morning he returns from the garden, Sa'di writes the chapter on the beauty of social interaction and the proper forms of conversation. In a text outlining the proper ways of being in the world and its moral meanings, as well as conveying a sense of the golden mean constituting social and political harmony, the narrator's true friend serves as an instrument of possibility, source of inspiration, and witness to the accomplishment of Sa dī-as-narrator. ${ }^{5}$

This was a different form of self-definition from that which marked a dominant strain of the modern normative European self. ${ }^{6}$ For example, Simone de Beauvoir notes, "Alterity is the fundamental category of human thought. No group ever defines itself as One without immediately setting up the Other opposite itself." ' She invokes G. W. F. Hegel, claiming that "a fundamental hostility to any other consciousness is found in consciousness itself; the subject posits itself only in opposition." ${ }^{8}$
In these articulations of an autonomous Enlightenment self as collective category, self-definition is predicated on a mutually exclusive sense of difference. This form of self-definition exists in Persian modernist writings as well. But simultaneously, and perhaps more important, up through the late nineteenth century (at least), it is the beloved friend through whom a modern and increasingly Iranian self was defined, a self based on intimacy, commonality, and similarity. ${ }^{9}$ It is in the lineaments of their intimacy that the constitutive meaning of the collective could be envisioned as ethical.

Divergently oriented Persian modernist writings (all written outside of Iran) evoke the figure of an Indian friend. In the one instance where this appears not to be the case, what has been taken to be enmity against the thought of Sayyid Ahmad Khan (1817-98) was articulated as warning against the false friend, a figure seen to undermine the socioethical structure within which the self in situ was embedded. These dire warnings were made to another Indian friend, consideration of whom places the text in a lineage of older notions of Persianate belonging. By the end of the century, as the Persianate self became explicitly (Iranian) national, the Indian friend was still present, and indeed integral to this emergence, though the terms of their intimacy had changed. His presence demands a reconsideration of modern national selfhood at the turn of the twentieth century and of the ways in which enduring forms of belonging shaped modes of self-understanding as something that happened in the first person plural, as "we" became modern together.

This older form of Persianate belonging enabled articulations of modern Iranian selfhood that simultaneously layered itself into collectivities called Muslim, Asian, and Indian. These overlapping affiliations are a notable feature of anticolonial imaginings of community that have all too often been segregated under the heading of
5. Ibid., 6-7. I discuss earlier Persianate ideas and practices of friendship in greater detail in Kia, "Transregional Ties That Bind: Forms of Companionship in Early Modern Iran and India," unpublished paper, last modified May 9, 2014.

6. Jan Goldstein locates this autonomous self in France as ascendant only after the 1830 s, with the cultural rise of the bourgeois. See Goldstein, The Post-Revolutionary Self.

7. Beauvoir, The Second Sex, 6.

8. Ibid., 7. For Hegel's notion of lordship and bondage that she references, see Hegel, Phenomenology of Spirit, 104-19. Edward Said also uses this relationship to describe an Orient cre- ated by a mode of Western self-definition, as "the Orientalist is outside the Orient, both as an existential and as a moral fact" (Said, Orientalism, 21).

9. For an explicit analysis of Iran's encounter with European modernity as formative of selfhood, see Cole, "Marking Boundaries." 
"pan-." They are part of a genealogy of nationalist thought that saw no contradiction between a unique Iran and a broader Asian or Muslim community with shared historical and/or cultural ties.

Most scholarship on late nineteenth-century Iran identifies two types of modernist thought seen to prefigure the great events of the twentieth century, the "secular" (usually anti-Muslim in the guise of antireligious) and the Muslim. ${ }^{10}$ Among the major names mentioned are Mīrzā Fath 'Alī Ākhūndzādah and Sayyid Jamāl al-Dīn Asadābādī "al-Afghānī," as well as the newspaper Habl alMatīn, edited by Sayyid Jalāl al-Dīn Kāshānī. These writers are all identified as "Iranian émigrés," a categorization that assumes an already constituted homogeneous national identity and precludes consideration of their broader identifications and interactions. Though not as they were in the early modern period, Persianate ideas and norms, such as those conveyed in a basic education, were still shared on a broader transregional level. ${ }^{11}$ These norms were taking on increasingly autonomous natures in South Asian contexts, rearticulated in Urdu in the face of direct colonial domination. ${ }^{12}$ But in the second half of the nineteenth century, older Persianate ethical norms could still function as a common lexicon between Iran and India. ${ }^{13}$ These continuities, and the social and political ties that they enabled, demand a reconsideration of Iranian and Indian modernity as interrelated. Within the writing of Ākhūndzādah, Afghānī, and the early Habl al-Matīn contributors, older Persian- ate ethical norms still prevailed, intertwined with the lingering memory of a once culturally intimate India, now connected to Iran in new ways.

The rule of colonial difference often acts as a scholarly iron curtain, separating any consideration of India from parts of the world not under direct colonial rule. ${ }^{14}$ It is assumed that colonial rule changed the fate of South Asia into something distinct from places like Iran. But if we look past the state and consider continuing trade networks and the social links that accompanied these transactions, we see that the circulation of people, texts, and ideas between the two lands continued. More than this, Iran was subject to political and economic pressures that spurred some of the same discussions around reform, though such discussions were about how to retain an embattled sovereignty widely seen to be under threat from European imperialism and internal decay. ${ }^{15}$ Colonial modernity saw literate Indians moving away from this shared Persianate past, but it was a gradual, switchback process, given the new modes of engagement between Iranians and Indians that continued into the early twentieth century.

These connections have also been absent in considerations of Iranian modernity, which tend to focus on Iran's interaction with Europe, in spite of the way in which many sources point to other locations. A recent scholar of the Iranian constitutional revolution states, for instance, that "increased interaction with European ideologies and cultures" was "expedited by a growing number of
10. See, for instance, Bayat, Mysticism and Dissent; Martin, Islam and Modernism; Afary, The Iranian Constitutional Revolution, chaps 1-2; and Vahdat, God and Juggernaut, which makes an autonomous self a central locus of modernity. Newer scholarship is beginning to contest this assumed bifurcation between the "secular" (European) and the Islamic. See Vejdani, "The Place of Islam in Interwar Iranian Nationalist Historiography," and Vejdani, Making History in Iran.

11. For what this education consisted of in the eighteenth century, see Kia, "Adab as Ethics of Literary Form and Social Conduct," 284-88.

12. See Pernau, "The Virtuous Individual and Social Reform."

13. For instance, Sa'dī's Gulistān was initially translated into Urdu under the patronage of the EIC at Fort William College as part of their efforts to develop Urdu as a prose language. See Mīr Shir 'Alī Afsūs's (1735-1809) translation, Bāgh-iUrdu (1802), which wasn't reprinted until the twentieth century (see Sharma, "If There Is a Paradise," 248-49). Many nineteenth-century versions were in Persian or had interlinear Urdu translations (Sa‘dī, Gulistān mutarjam [1882]). For an example of another early Urdu translation, see Sa‘dī, Gulistān-i mubtadī (1845).

14. At the level of the colonial state, this means a power dynamic shaped by "the preservation of the alienness of the ruling group," thus enshrining modern Orientalist understandings of difference in modes of state governance (Chatterjee, The Nation and Its Fragments, 10; see also 16-27). Chatterjee's distinction is useful in discussions about a Euro-American history of the state and its forms of power "in the countries of Asia and Africa" (14). But there are countries in Asia that did not experience direct co-
Ionialism (even within the subcontinent itself), and consideration of their place in relation to metropole and colony has only just begun. See, for instance, Beverley, Hyderabad, British India, and the World.

15. There is not much difference in a formally uncolonized place like Iran and trends that Chatterjee ascribes to the rule of colonial difference. There, too, the "nationalist response was to constitute a new sphere of the private in a domain marked by cultural difference: the domain of the 'national' was defined as one that was different from the 'Western'” (Chatterjee, The Nation and Its Fragments, 75). The origin and impetus of many Iranian reform projects were forged in contexts of imperial coercion and the perceived looming threat of colonial rule. See Kia, "Moral Refinement and Manhood," and Kashani-Sabet, Frontier Fictions. 
Iranian merchants and others traveling to India, the Ottoman Empire, Egypt, Russia or to Western Europe." ${ }^{\prime 16}$ But in the subsequent analysis, they are portrayed as coming into contact with solely European ideas in these places. How might our picture of modernity, colonial or otherwise, change if we were to take these contexts seriously, as significant factors in the process of exchange, learning, and translation? Late nineteenth-century modernist discourses advocating reform addressed, and engaged in dialogue with, wider audiences of Persian speakers in other locations, not all of whom came to call themselves Iranians. ${ }^{17}$ They were part of a transregional dialogue that needs to better examined, especially if we are to understand the nineteenth century on its own terms, as a time when possibilities of imagining selves, communities, and futures exceeded the narrower demands of later forms of nationalisms. ${ }^{18}$

\section{The True Friend as Locus of Moral Transformation}

One striking aspect of Persian modernist writing is its dialogic form, in which the interlocutor is often posed as a friend..$^{19}$ These dialogues are predicated on a self that is dependent on social relationships for actualization. As a form, dialogue has a long history, most famously in the form of Socratic dialogues and also in premodern Persian literature. ${ }^{20}$ There is a link between European philosophy's emphasis on an autonomous self and its move away from the dialogic form. Instead of achieving dialectic transformation through the synthesis of the polyvocal dialogue, philosophical writing became more direct and univocal, a form to enable a solitary realization of the self. ${ }^{21}$ More recent formulations of dialogue pose the self and its other as mutually constitutive, but this configuration is still built on dialectic opposition. ${ }^{22}$ What happens when dialogue takes place not between two oppositional interlocutors, but between Persianate friends? The figure of the friend is not just a rhetorical device by which the narrator can elucidate a point; because of the transformative possibilities of such interaction, he is an important means of attaining moral perfection.

Akhundzadah $(1812-78)$ draws on and deploys the trope of friendship in his most incendiary work, which is designed as an attack on religion. In his Letters of Kamāl al-Dawlah, Ākhūndzādah makes use of this ethical language in his fictional epistolary dialogue between two princes, Kamāl al-Dawlah, an Indian prince traveling in Iran, and Jalāl al-Dawlah, an Iranian prince. Much has been made of Ākhūndzādah's glorification of a pre-Islamic Iranian history, decoupled from and set in opposition to a modern concept of religion in order to create the basis of legitimacy for wholesale Europeanization. As Reza Zia-Ebrahimi notes, an idealized pre-Islamic Iran was given the essential characteristic of a true Iranian national selfhood, set in radical opposition to its Other, Arabs, to whom Islam belonged. "Savage" Arabs had imposed Islam on Iran by force of arms, and it was this unnatural imposition that caused Iran's
16. Bonakdarian, Britain and the Iranian Constitutional Revolution, 14.

17. Readers of Habl al-Matin in Calcutta and Rangoon were often from merchant families whose fathers or (great) grandfathers had migrated and who themselves never lived in Iran, remaining in Burma or else relocating to British India and/or later Pakistan.

18. This dialogue is similar to, but wider than, what has been called the colonial public spheres in the Indian Ocean. See Hofmeyr, "Gandhi's Printing Press"; Hofmeyr, "The Complicating Sea"; Frost, “'That Great Ocean of Idealism'”; and Frost, "Asia's Maritime Networks and the Colonial Public Sphere."

19. The dialogue was used in the writings of the famous nineteenth-century reformer Mirzā Malkum Khan (for instance, "Rafiq va vazir" ["The Minister and His Companion"]). The fig- ure of the friend is also instrumental in Mìrzā Yusuf Khan Mustashār al-Dawlah's (d. 1895) Yik Kalamah ("One Word"). For more on the topics of these works, see Rezaeiyazdi, "The Dialogic Tradition of Iranian Modernity." Modernist writings in India were written in the form of dialogues as well, even as late as Gandhi's Hind Swaraj (1909). While Gandhi's interlocutors are labeled "reader and editor," in the preface to the English translation he notes that "some of the friends who have read the translation have objected that the subject matter has been dealt with in the form of a dialogue. I have no answer to offer to this objection except that the Gujarati language readily lends itself to such treatment and that it is considered the best method of treating difficult subjects ... the dialogue, as it has been given, actually took place between several friends, mostly readers of Indian Opinion, and myself" (Gandhi, Hind Swaraj, 6).
20. There is surprisingly little on the dialogic form in premodern Persian literature. For a largely descriptive treatment, see Hardy, "The 'oratio recta' of Baranī's 'Ta'rīkh-i-Fīrūz Shāhī.'” I thank Mohsen Ashtiany for this reference. Scholarship on modern Iranian dialogues assume this classical tradition, without any direct discussion. See, for instance, Rezaeiyazdi, "The Dialogic Tradition of Iranian Modernity," 2-3.

21. See Nikulin, Dialectic and Dialogue. For the importance of conversation for ethicodidactic purposes and its vaunting by Plato over the self-sufficiency of internalized dialogue, see Long, Conversation and Self-Sufficiency in Plato. From the seventeenth century, thinkers such as René Descartes considered dialectic transformation without dialogue to be a more scientific and systematized form of rationality.

22. See Maranhão, "Introduction," 4 
present debased state. ${ }^{23}$ While many of these ideas were an early articulation of historical thinking that would gain importance in post-WWI Iranian nationalism, Ākhūndzādah's wholesale dismissal of Islam was not widely shared in the nineteenth century. ${ }^{24}$ However, the text's neglected frame provokes the question, why does a Tbilisi-based Azeri intellectual choose to make his Iranian prince's interlocutor a descendent of a Mughal emperor?

The Letters of Kamāl al-Dawlah has been called "a fictive travelogue," celebrating pre-Islamic Iran "through the persona of a foreign traveling prince." ${ }^{25}$ But this is not how the text presents itself. Rather than "a foreign traveler," Kamāl alDawlah is identified as a descendant of "Ālamgir Awrangzib (r. 1658-1707) and a dear friend of the Iranian prince Jalāl al-Dawlah. Even the parallel structure of their titled names strongly suggests a common framework of cultural intelligibility.

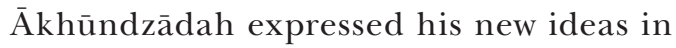
terms of older and still-dominant ideas derived from early Qajar Iran-ideas that continued to bear the imprints of sustained intimacy with India left over from their shared early modern Persianate culture. Kamāl al-Dawlah gives advice, playing the role of the friend outlined by akhlāqi norms. The first letter addresses Jalāl al-Dawlah: "Oh my dear friend [ay dūst-i 'azizz-i man]." The writer is a presumably Shi'i descendent of 'Ālamgir, since he identifies himself as being of the same sect $(m a z h a b)$ as the people of Iran. ${ }^{26} \mathrm{He}$ describes how sad his arrival in Iran has made him (jigaram kabāb shud), then addresses Iran in general (ay Iran), asking where its grandeur and happiness (shawkat va sa'a dat) from the days of Kiyamarz, Jamshīd,
Gushtāsp, Anūshīravān, and Khusraw Parvīz have gone. ${ }^{27}$ Later he also talks about Firaydūn and Rustam and references Firduwsī and the Shähnāmah. ${ }^{28}$ None of these historical figures, authors, or texts are new to early modern Persianate historical narratives in either Iran or India. ${ }^{29}$

The framing letter describes Kamāl alDawlah as Awrangzib's degenerate (nä-khalaf) son because "he has penned his depraved views with the purpose of striking a blow against the beliefs of the religion of Islam," making him a heretic atheist (zanädiqah). ${ }^{30}$ This should not be understood as a demonization of the memory of the Mughals. In this letter, Ākhūndzādah-as-narrator argues for the need to respond calmly, without punishment and with wisdom, to such views, claiming that they have long existed in Muslim history and been dealt with thus, just as they have in modern Europe. ${ }^{31}$ Written in the voice of a believer, this framing letter was meant to position the reader to consume the dialogue in a particular way. Kamāl alDawlah serves as a mouthpiece for Ākhūndzādah's own views, yet Ākhūndzādah-as-Muslim-narrator marks him as depraved ( $f \bar{a} s i d$ ) in order to distance himself from Kamāl al-Dawlah's radical views. $\bar{A} k h u ̄ n d z a \overline{d a h}$ enjoins the reader to listen to him, if only so as to counter his views. It is an incitement to critical engagement.

After narrating the terms under which the Persian empire became Muslim, Kamāl al-Dawlah declares, "This is how we came to accept Islam." ${ }^{2}$ This Mughal prince is part of the ancient Persian community that accepted Islam; he is "we" together with Jalāl al-Dawlah. These are echoes of the continuing intelligibility of 'ajam, a sense
23. For example, see Ākhūndzādah, Makhtūbāt, 158-62. On these arguments and their larger context, see Kia, "Mirza Fath Ali Akhundzadah"; Sanjabi, "Rereading the Enlightenment"; Tavakoli-Targhi, Refashioning Iran, 99-104; Vahdat, God and Juggernaut, 42-48; Marashi, Nationalizing Iran, 54-75; and Zia-Ebrahimi, “'Arab Invasion' and Decline."

24. See Kia, "Moral Refinement and Manhood in Persian." Vejdani argues that even during the Pahlavi era, official nationalism was not explicitly anti-Islam ("The Place of Islam"), though Zia-Ebrahimi argues otherwise ("Arab Invasion' and Decline," 2-4).

25. Mottahedeh, Representing the Unpresentable, 14.
26. Ākhūndzādah, Makhtūbāt, 15.

27. Ibid., 16.

28. Ibid., 20, 23, 27.

29. This is part of a larger disconnect between early modern and modern scholarship; little work has been done on what was really new in late nineteenth-century interpretations of preIslamic Persian history. What does seem novel is mention of figures that populate Greek and biblical sources, like the Achaemenid kings. But that the mid-nineteenth-century narratives were entirely novel and radically different from previous understandings is part of modernists' own broader claims of radical rupture with the traditional past. Knowledge of European narra- tives did circulate through the Qajar court, but it is unclear if Ākhūndzādah would have had access to such texts. One example of this circulation is the Calcutta-based Abū Tālib Khan's famous 1803 travelogue, which draws on Greek histories translated into English to clarify the relationship in ancient times between farang and 'ajam, which he translates as Europe and Asia (Ma'āsir-i Tâlibì, 349).

3o. Ākhūndzādah, Makhtūbāt, 4.

31. Ibid., 3-4.

32. Ibid., 31. 
of affiliation and similitude beyond Iran that is particularly noteworthy in the work of someone whose sharp delineation of national self was posed against Arabs. By contrast, a Persianate India with its Mughal emperors still lingered even in the imagination of a Tiblisi-based Azeri intellectual, who styled Kamāl al-Dawlah's words as the advice of an ethical friend. Ākhūndzādah's post-Mughal, but not post-Persianate, Kamāl al-Dawlah addresses the Iranian Jalāl al-Dawlah from within the intimacy of friendship. While a self-other distinction animates certain parts of the text, the overwhelming means by which the modern Iranian self is brought into relief is through intimacy with the beloved Indian friend, a much older form of Persianate self and collective realization.

\section{The False Friend as Agent of Moral Debasement}

More dominant than Ākhūndzādah's ideas, and more centrally located in older Persianate conceptions of self, social collectives, and polities, were those expressed by Sayyid Jamāl al-Dīn 'Asadābādī "al-Afghānī" (1838/39-97). ${ }^{33}$ Afghānī is best remembered for his propagation of "pan-Islamism," an ideology of anticolonial resistance undertaken through social and intellectual reform according to what has been called "a rationalist Islam" and through Muslim political unity. ${ }^{34}$ While Afghānī had always been antiimperialist (particularly antiBritish) but advocated for acquisition of European science and technology, his reformist writing and teaching did not articulate a defense of religion until his most famous Persian treatise, Haquqqat-i mazhab-i Naychirì va bayān-i hāl-i Naychiriyān (The Truth about the Naturist Sect and an Explanation of Their State).${ }^{35}$ Afghānī defines Naychiris as those who do not believe the existence of anything save matter perceptible with the five senses. For Naychiris, the primary cause of everything is nature $\left(t a b^{\circ}\right)$, rather than the divine. A person with such beliefs is a $t a b i^{i} \bar{\imath}$, which he translates as Naturist (naychirī) or Materialist. ${ }^{36}$ Beginning with ancient Greek philosophers, Afghānī traces the various schools of this sect into modern times, one of which is best exemplified by Charles Darwin. ${ }^{37}$ Enlightenment-era thinkers such as Voltaire and Jean-Jacques Rousseau exemplify another school of Naychirīs; proof of their status lay in their instigation of the French Revolution..$^{38}$ The text was composed after his encounter with Sayyid Ahmad Khan's followers in Hyderabad (188o-82), whom he found to be blind imitators of British ways. ${ }^{39} \mathrm{He}$ unites this type of reformer with other seemingly unrelated types of people under the category of Naychiris, whom he describes as morally debased corrupters of civilization. By contrast, for Afghānī, Islam serves as the basis of a common body of knowledge that should act as the core of culture and should structure the life of Muslim nations.

That this text is an attack on Naychiris, most
33. On Afghānī's life and work, see Keddie, $A n$ Islamic Response to Imperialism, 3-35.

34. On pan-Islamist ideas articulated in Persian, see Kia, "Pan-Islamism." I have put the term in quotation marks because it has been used to label such a large variety of ideas that it is an imprecise signifier at best. As Mehrdad Kia's article shows, not all those who used the term Ittihād-i Islam (unity of Islam or Islamic universalism) were preoccupied with Ottoman sovereignty. For some, like Afghānī and the editors of Habl al-Matin, it meant a set of ideas that gave meaning to the world by and through which social and political practices could be derived. European practices could be adopted, but they had to be filtered through something understood as Islam. Proponents of Ittihād-i Islam thus claimed a kind of universalism for Islam that could engender transregional affiliations and thus solidarity. This unity was not based in homogeneity and was acknowledged to contain specificities of language, polity, etcetera. For a recent work on Ottoman-centric no- tions of pan-Islamism, see Aydin, The Politics of Anti-Westernism, 31-37, 59-69. Aydin notes its polycentric nature and variety of visions, sharing the characteristic of Islam as a basic common bond, in spite of differences, but hardly mentions Afghānī or any Persian articulations (61). For a take on Afghānī emphasizing his anticolonial politics, see Mishra, From the Ruins of Empire, 49-123.

35. Juan Cole notes that Afghānī based his reformist modernism in a religion refigured through the related fields of Illuminationist (ishrāqi) and moral (akhläqī) philosophy, most recently in their early nineteenth-century Shaykhī/Bābī interpretations (Cole, "New Perspectives," 16-17). Also see Keddie, An Islamic Response to Imperialism, 9-11. For more on akhlāqi literature, see Alam, Languages of Political Islam, 46-69. For a basic overview of Illuminationlist thought, see Marcotte, "Suhrawardi." For more on Shaykhī thought, see Bayat, Mysticism and Dissent, 37-58.
36. Afghānī, Haqĩgat (1881), 7-8, and Afghānī, Naychirìyah (1948), 10-11. To retain the specificity of Afghānī's definition, I retain the transliterated term, Naychirī. Below I cite the 1948 Tabriz version, which follows the 1881 Bombay version exactly. For an English translation, see Keddie, "The Truth about the Neicheri Sect," 130-74.

37. Afghānī, Naychirīyah, 13.

38. Ibid., 37.

39. On this encounter, see Ahmad, "Sayyid Ahmad Khān," and Keddie, An Islamic Response to Imperialism, 21-22. Afghānī's tract was published in Hyderabad in $\mathrm{AH}$ 1298/1881 and was translated into Arabic by Muhammad 'Abduh as "Refutation of the Materialists" in 1886. See Keddie, An Islamic Response to Imperialism, 54-55. 
vividly inspired by the Westernizing reformism of Ahmad Khan, may at first seem the kind of external antagonistic relation according to which the autonomous Enlightenment self defines itself. Naychiris are framed as an existential threat to the morally perfect self and community. But Afghān̄̄ presents his attack as the warning of a true friend against the danger to moral substance posed by the Naychiris as false friends. In the language of ethical Persianate friendship, the threat of the false friend comes from within the self's society. This self-constitution does not depend on the alterity of a binary Other, as is envisioned by Beauvoir. Alterity tells a story of a self-coming-into-being through opposition, whereas the true friend's warning tells of a coming-into-being by ethically interacting with others. If we think of the self as a synecdoche of a collective, Afghānī's formulation has three figures. The true friend must help the individual realize the nature of the false friend and contain his power to defile the community, as one would a vice. The friend acts as one who is speaking to an "I," with whom he also makes up part of a "we."

The intimacy of the friend frames the treatise as a whole, which opens with a letter (dated AH 19 Muharram 1298/ 22 December 1880) written by Muhammad Vāsil, a mathematics instructor at Madrasah-yi A'izzah in Hyderabad, asking for the truth about Naychirīs. Vāsil inquires about those who have placed Naturism as an alternative to Islam as a basis for civilization/social order (madaniyat). He asks what its effects on civilization are compared with religion $\left(d_{\bar{\imath}} n\right)$, and if the two are compatible. Afghān̄̄'s treatise is appended to his response, which begins with the address, "oh my dear friend [ay dūst-i 'aziz]]," coding what follows as an ethico-didactic exchange meant to engender a higher level of understanding in the reader, who hears the words of the true friend together with Muhammad Vāsil. ${ }^{40}$

In response, Afghānī explains, "the essential goal of this people [tā'ifah] [Naychirīs] is the abolition of religions and the establishment of a foundation for unrestrained license [ibāhat] and communal possession [ishtirāk] amongst all people." ${ }^{41}$ This is a claim of universal danger, given in broader Islamicate terms but enframed according to a specifically Persian narrative that becomes the lens through which the appearance of Naychirīs in other times and places is read. The figure of the Naychirī strongly echoes that of the heretic in the well-known twelfth-century Persian political advice text Nizām al-Mulk's Siyar al-Mulūk. In this text, the prescribed restraints of religion and government undergird social distinctions, which are considered the basis for the moral individual and the ordered collective. It is from the corruption of religion and government that the heretics' goals of license and communal ownership derive. These particular terms are keyed to the archetypal corrupter in a Persian ('ajam) context, Mazdak, to whom Afghānī later refers by name. ${ }^{42}$ In Siyar alMulūk, Mazdak is a figure responsible for all manner of vice and depravity, including the communal sharing of women and the abolition of property and rank, resulting in fitnah, total chaos. ${ }^{43}$ Put another way, ibāhat also means liberty from restrictions, a valorized idea in European liberal thought, but here a deeply ambivalent state at best and a depraved state at worst. ${ }^{44}$ This association between liberty from restraint and social chaos undergirds the work as a whole. Afghānī explains to his friend, "In every [religious] community [ummat] in which this faction $\left[j a m \bar{a}^{6} a t\right]$ has appeared, they have corrupted the morals of that community and been the cause of its decline $[z a v \bar{a} l]$. If one were to deliber-
40. Afghānī, Naychirīyah, 8-9. These framing letters are a stable feature of all the editions I consulted. For instance, see Afghānī, Haqiqat, 4-6.

\section{Afghānī, Naychirīyah, 9.}

42. Ibid., 33-34. Nizām al-Mulk identifies these "heretics" (bad-mazhabān) in general terms as "the enemy of government and Islam" but states that he will provide a specific example of such a figure in Persian lands (Siyar al-Mulūk,
254-56). He then tells the story of Mazdak and how Anūshīrvān counteracted this dangerous figure's influence (Siyar al-Mulūk, 257-73). Afghānī makes this figure universal by extending its relevance beyond Muslim dominions.

43. Nizām al-Mulk even uses the same word to describe the abolition of private property ( $i b \bar{a} h$ at-i māl). Communalization of women is the next consequence resulting from the lifting of lawful restraints (Siyar al-Mulūk, 259-60). For more on the figure of the heretic in Per- sian historiography as it was evoked in Safavid Iran, see Babayan, Mystics, Monarchs, Messiahs, 47-56. For more on political advice literature, see Yavari, Advice for the Sultan, and Arjomand, "Perso-Islamicate Political Ethic."

44. Gubara has drawn the same distinction, arguing that discussions of slavery in the Muslim context need to be undertaken in a hermeneutical context that does not presuppose Europespecific ideas of freedom and individual sovereignty. See Gubara, "Beyond Freedom." 
ate on the origins and aims of this group [gurūh] it will become well evident that there will be no other consequence of their opinions than the corruption of civilization [madaniyat] and the ruin of the social structure." This is because "religion is absolutely the link of social order, and without religion the foundation of civilization will never be strong." ${ }^{45}$ The word translated as "civilization" by the late nineteenth century, madaniyat, had been used in early modern and medieval contexts for a constitutive order of the polity structuring social and political relationships. ${ }^{46}$

This letter acts as an abstract of the treatise itself, which, "God-willing, will be agreeable to the dear discernment [khirad-i'aziz] of that learned friend [sadīq-i fäzil]." ${ }^{97}$ In making his friend aware of the truth about this sect, Afghānī positions his treatise as the work of an ethical friend of the highest order, meant to be worthy of the understanding of his learned friend, even as it enriches that understanding, thereby strengthening the moral substance of the collective. Sadī is the term in Persian moral philosophy that specifically denotes a sincere or true friend, in contrast to those with selfish motives for friendship. ${ }^{48}$ In the body of the treatise, Afghānī frames his exposition of the true meaning of Naychirīs as something incumbent (vājib) upon him..$^{49}$ Calling something vājib gave it the cast of a prescribed duty manifesting religious belief, but in the epistolary frame, its object as an obligation to God is conflated with the duty to the friend as a synecdoche of the community. So while this text was written against the brand of reform espoused by Sayyid Ahmad Khan, the ethical association with a Hyderabadi friend constitutes a righteous modern self. Afghānī embeds this self in an Islamic social order, but the idiom of that self is specifically Persianate.

Aziz Ahmad has noted that not much distinguished Afghānī from his purported nemesis and that he never actually names Ahmad Khan in the treatise. ${ }^{50}$ The main issue was that Afghānī perceived Ahmad Khan's rationalist approach to religion as an attempt to conform to self-universalizing/European civilization and its basis in natural law. ${ }^{51}$ Such an approach evacuated religion's supernatural elements and replaced them with naturalistic explanations that sapped the authority from the divine injunctions that for Afghānī were the basis of civilization..$^{52}$ These varied theological interpretations gave rise to more obvious differences with respect to education and politics. ${ }^{53}$

However, anti-Naychirism cannot be understood as a simple metonym for anti-Westernism. The category of Naychirī extended far beyond Ahmad Khan, or even his brand of reform. It linked Bābīs, atheist Greek philosophers, Enlightenment thinkers, democrats, communists, westernizing reformers, mystics (Muslim and otherwise), and others, all of whom mistook materialism for rationality, resulting in corruption and the ineluctable decline of any community that allowed itself to be swayed by their views. ${ }^{54}$ Within this huge and seemingly disparate category, which usually wore the better-known face of the heretic or revolution-
45. Afghānī, Naychirīyah, 9.

46. Kia, "Moral Refinement and Manhood in Persian."

47. Afghānī, Naychirīyah, 9. Fāzil can also mean virtuous.

48. Two of the most widely read Persian moral philosophy texts in early modern Iran and India use this word to define ideal friendship; see Tūsī, Akhlāq-i Nāsirī, 321-34, and Davvānī, Akhlāq-i Jalālī, 281-86.

49. Afghānī, Naychirīyah, 9.

50. Ahmad, "Sayyid Ahmad Khān," 58-59. Ahmad's contention about their differences is rather unsatisfying. He claims that Ahmad Khan was "concerned with the particular, the concrete, the detailed; while his adversary was concerned with the general, the generalized and the emotionally surcharged abstract" (58). For a more nuanced consideration, see Mishra, From the Ruins of Empire, 91-96.

51. Moaddel, Islamic Modernism, 63-65.

52. Lelyveld has noted that in Ahmad Khan's reformulation of Islam to prove its consistency with nineteenth-century European rationalism, "the truth of Islam was always prior: modern scientific ideas were either consistent with Islamic doctrine, or they had to be refuted. On the other hand, he was prepared to simplify received doctrine and to forgo transcendental acceptance of the supernatural ... by taking great pains to provide naturalistic explanations for specific miracles related in the Qur'an" (Aligarh's First Generation, 110-11).
53. Ahmad, "Sayyid Ahmad Khān," 56, 58-62. Moaddel contends that Afghānī's "quarrel with the West, Britain in particular, was political," and that his attitudes with respect to education and its attendant moral and intellectual development were derived from European thinkers (87). This categorization overlooks the way in which some European ideas to which he was exposed resonated with well-established philosophical ideas from the akhläqi and ishrāqi traditions. These resonances energized new reinterpretations, making Afghānī's views less an issue of "influence" of European works and more a matter of "transplantational translation," a process I outline in Kia, "Moral Refinement and Manhood in Persian."

54. Afghānī, Naychirīyah, 17-18. 
ary, Ahmad Khan and his ilk of modernizing reformers are the most dangerous.

Those deniers of divinity, or Naychirīs, who have come in the deceptive clothing of refomer [muhazzab], as friends of the community and wellwishers of the people, have made themselves both the partners of thieves and companions of the caravan and have lifted the banner of their learning and experience before the rich and stupid... . It is not possible for someone to be a Naychirī and despite this to be a reformer of morals or to be trustworthy, sincere, manly/virtuous and chivalrous [sāhib-i amānat va sidāqat va murūvat va javānmardī]..$^{55}$

These last descriptors speak in the language of Persianate morality, uttered as idealized masculinity or rather, in the Naychirī's case, its lack. It is precisely because they spoke the same language of Persianate moral refinement that Afghānī perceived Ahmad Khan's brand of Naychirīsm as such a threat. Ahmad Khan's most famous publishing venue was his newspaper, Tahzīb al-Akhlāq (Refinement of Morals). He was not the more clearly marked European Other; rather, he was the false friend, a cultural insider, whose deceit was that much more dangerous. The Naychirī-as-reformer was the partner of thieves, even as he posed as a trusted caravan companion. By contrast, Afghānī's warning marks him as a true friend, both to the Hyderabadi interlocutor and to his wider Persianate audience.

This transregional relationship with the Indian friend is less imaginative than Ākhūndzādah's; it was the result of actual travel and contact, mimicked by the circulation of its textual expression. The treatise was first lithographed in Hyderabad in AH 1298/1881 and soon after in Bombay. ${ }^{56}$ This more widely circulating Bombay edition already bears the paratextual marks of transregional readership. An enthusiastic review of the treatise written by the editor of Farhang, an Isfahani news- paper, prefaces the text proper, which begins with the letter of the Hyderabadi friend ${ }^{57}$ This exact version, with the Farhang editorial preface, was published in Rasht during the constitutional revolution. ${ }^{58}$ Even as late as 1948 , the Tabriz print edition began with a preface by the press's editor (in place of the Farhang preface) and preserved the main treatise within the frame of this epistolary exchange between the Hyderabadi instructor and Jamāl al-Dīn. ${ }^{59}$ Two different Urdu translations appeared in 1945 and 1946, in Lahore and in Hyderabad, respectively, signaling Afghānī's reccurring relevance in discussions leading up to independence. ${ }^{60}$ Given that Afghānī does not mention Ahmad Khan by name, this association may very well have faded from these twentieth-century Persian and Urdu publications. What survives is the Hyderabadi friend as figure of the Persianate collective, whom Afghānī warns of the hidden dangers of the false Naychirī friend bearing the poisoned gift of modernity-as-dissolution.

\section{Modern Intimacies with the Indian Friend}

It is often claimed that Afghānī's influence was negligible in India, where preoccupations with pan-Islamism began only in the second decade of the twentieth century, with Abūl Kalām Āzād's influential periodical al-Hiläl, the 1912 humanitarian aid mission to Ottoman forces in the Balkans (both based in Calcutta), and the Khilafat movement. But, if "the more vigorous campaign in support of the Ottoman Caliphate would come in the early 1920 in the form of a countrywide agitation," how and why did "pan-Islamism" appear at this time in India, well after the Ottoman-sponsored pan-Islamism had faded away? ${ }^{61}$ Answering this question requires separating a number of things, one of which is the question of whether the impetus behind these activities is the same. Nile Green has recently proposed the term trans-Islamic as an alternative to pan-Islamist, referring to "paral-
55. Ibid., 40-41.

56. Green, Bombay Islam, 151.

57. For the review, see Afghānī, Haqiqat, 2-4.

58. This version was published under the title Ibtāl-i Tariqah-yi Tabīîiyin.
59. It was also previously published in Tehran in 1933. The 1948 edition claims to correct the many errors of the Tehran edition by drawing on the 1881 Bombay lithograph, which was in the possession of Hajj 'Abbās Qulī Va'iz Charandani (Afghānī, Naychirīyah, front matter). 6o. Afghānī, "Haqiqat-i Mazhab-i Naychiri va Naychirian," 11-79. Also see Afghānī, Irshādāt Jamāl al-Dinn Afghānī. I was not able to look through the Lahore translation.

61. Mishra, From the Ruins of Empire, 95. For Khilafat as pan-Islam, see Minault, The Khilafat Movement. Also see Douglas et al., Abul Kalam Azad. 
lel but usually discrete global developments" that "were neither unified as a single movement nor aimed at common or collective goals." ${ }^{\prime 2}$ If the desire to unite politically under the Ottoman caliphate is the central feature of pan-Islamism, then the Khilafat movement certainly falls under its auspices. But other types of activities concerned with nationalism, anticolonialism, pan-Asianism, and modernizing reform, as well as a shared bond around Islam, must be distinguished from Islamic universalism, though not in a mutually exclusive way. They all coalesce around the concept of an alternate universal ethics that was put to sometimes diverging purposes. In the context of its Persian articulations, trans-Islamism could accommodate multiple allegiances, some based on being Muslim, but others based on the continuing shared sensibilities and translocal ties that had once bound a Persianate world socially and culturally. These circuits of contact had brought Afghānī to India, led him to communicate in Persian, and continued to constitute modernist ideas in both Iran and India.

One such instance of continuing contact was the Calcutta-based Persian-language weekly newspaper Habl al-Matīn (The Firm Rope) ${ }^{63}$ Recent scholarship on Iran has identified Habl al-Matīn as one of the most important newspapers of the Constitutional period (189o-1912) ${ }^{64}$ But little attention has been paid to the fact that for most of its long run (1893-1930) this newspaper was located in Calcutta (the capital of British India until 1911), and that its editor, Sayyid Jalāl al-Dīn Kāshānī "Adīb" Mu'ayyad al-Islam (1863-1930), was simultaneously active in Iranian nationalist and local Bengali politics. Janet Afary calls Calcutta's Habl al-Matīn a "pan-Islamist exile paper," but what does "panIslamist" mean in a context that does not advocate political unity behind the Ottoman sultan? ${ }^{25}$ Early Habl al-Matīn's trans-Islamic agenda advocated a reformed modern national self that defined itself in intimate relation with others. These earlier issues explicitly locate the paper in Calcutta and address themselves to a mobile population of Persian speakers with largely translocal mercantile interests. If this can be called a nationalist Iranian newspaper, because it is written in Persian and is (partly) concerned with Iranian politics, then nationalism in this form needs to be redefined. Early Habl al-Matinn provides a view of an expansive Iranian self-definition, a Persianate modern that drew on an eclectic mix of British Indian, Islamic universalist, and pan-Asian associations to map a vision of collective ethics of affiliation, according to new forms of intimacy.

Habl al-Matìn and its editor are almost entirely absent from scholarship on Muslim politics in India. ${ }^{66}$ This scholarship generally distinguishes pan-Islamists from Ahmad Khan and his ilk, based on an anticolonialism that was also against communally based politics such as those initially espoused by the Muslim League. ${ }^{67}$ But such distinctions cannot be applied to these translocal multilingual Muslims in Calcutta, who were simultaneously involved with the Bengal Muslim League and Iranian Constitutional politics. Such actors have been dismissed either because they do not represent strands of thinking that became important later (such as exclusivist nationalism),
62. Green, “Forgotten Futures,” 612.

63. The press itself published other newspapers and books, both in Persian and in Urdu and English. It has been claimed that the press also published an Urdu edition of Habl al-Matin, as well as another Urdu newspaper called Calcutta and an English newspaper called Mulk va Millat (Country and Nation), though the author cites colonial newspaper lists, not the papers themselves (Parvin, "Habl al-Matin"). For a Habl al-Matin Urdu publication, see Mīrzā Muhammad Rafi' Saudā, Muntakhab-i masnaviyyāt-i Saudā (1903), a text for the High Proficiency Examination in Urdu. The press also published textbooks for exams in Persian, such as Habibullah Qa'ani Shirazi, Selections from Qaani (1907). Other books published by the press include Ibrāhīm Beg's Siyāhatnāmah (1910), Husayn 'Alī Tājir Shirāzī's Mikādūnāmah (1907, about the 1905 Russo-Japanese war), and Persian translations of Jirji Zaydān's Tārīkh-i Tamaddun-i Islämī (1911) and Morgan Shuster's The Strangling of Persia as Kitāb-i Ikhtināq-i Iran (1915).

64. Janet Afary notes that between 1905 and 1911 over two hundred periodicals began publication (The Iranian Constitutional Revolution, 116). Also see Nabavi, “Journalism i. Qajar Period," and Moaddel, Islamic Modernism, 113.

65. Afary, The Iranian Constitutional Revolution, 118, and Nabavi, “Journalism i. Qajar Period."

66. See, for instance, Jalal, "Exploding Communalism," and Ahmed, Bengal Muslims. An exception is Rahman, From Consultation to Confrontation. Sarkar mentions the paper, drawing on the same colonial records on Indian newspapers cited by Sims-Williams, "The Persian Newspaper." As far as I can determine, no scholars of South Asia seem to have actually read the newspaper itself.

67. The historiographical script dealing with the late nineteenth to early twentieth centuries moves from Ahmad Khan to his student Hali, their revivalist critics, Afghānī's trans-Islamic critique, local critics such as Shibli Numani and Akbar Allahabadi, and finally to the rise of Islamic universalism from 1912. For further discussion see Jalal, "Exploding Communalism," 81-87. 
or else because they are deemed to be too elite, and thus irrelevant to a presumed (nationally) authentic Bengali-speaking majority. ${ }^{68}$ If we put the concerns of hindsight and authenticity aside, we may tease out a story of the continuing possibilities of belonging in the late nineteenth century, one that could accommodate multiple simultaneous allegiances-local, nationalist, and transregionalthat were not deemed to be in contradiction with one another. This also allows for the possibility that individuals who came to espouse "panIslamism," such as Āzād, engaged with more than Arabic reformist thought; they were also attuned to the kind of Persianate reformist ideas being articulated closer to home, by the Calcutta-based Habl al-Matīn. ${ }^{69}$ Indeed, Sumit Sarkar entertains the possibility that "it is not unlikely that some of the Bengali Muslims who joined the national movement in the 1905 days had been swayed by the bitter anti-West propaganda being carried on by the Calcutta-based Persian weekly" Habl alMatinn, an "organ of exiled Iranian patriots." ${ }^{70}$ How precisely a paper that lauds the fiscal and administrative structure of the colonial state, even as it rails against British imperial sovereignty, can be understood as engaging in "bitter anti-West propaganda," at the very least requires clarification. ${ }^{71}$

According to colonial records, Mu'ayyad alIslam settled in Calcutta in 1888, where he conducted business with Singapore. He had allegedly met Afghānī in Bandar 'Abbas and corresponded with him and Mīrzā Malkum Khan while the two were in London in the early 1890 os. $^{72}$ The newspaper's very title, which translates to "The Firm Rope," is perhaps meant to echo Afghānī and Muhammad Abduh's Paris-based Arabic newspaper, al-'Ūrwa al-wüthqū (The Strongest Link, 1884). ${ }^{73}$

Early Habl al-Matīn rhetoric identified civilization as the institutional feature of modern life and used terms linking it to an Urdu-speaking context. This connection is unsurprising, since Mu'ayyad al-Islam was, along with other nonBengali local Muslims (some from Iran and some from other parts of India), involved with the Bengal Muslim League. ${ }^{74}$ However, unlike a number of his political associates, Mu'ayyad al-Islam was opposed to British colonial rule in India, as well as to cultural Europeanization..$^{75}$ Along with several members of the Bengal League, including other migrants from Iran and their descendants, he later participated in the formation of the Indian Red Crescent Society, which sent humanitarian aid to Ottoman Turkey during the first Balkan war. ${ }^{76}$ However, in spite of this opposition to European sovereignty and cultural emulation of Europe, $\mathrm{Habl}$ al-Matīn universalized and lauded various features of colonial administration as necessary reforms toward modern progress. For instance, in an article titled "The Progress of India's Post," Europe's post is described as a system, part of Europe's greater "progress in civilization [tamaddun va tahzī b] and in teaching and learning [ta'līm va ta'alum]." ${ }^{\prime \prime 7}$
68. For the latter view, see Ahmed, Bengal Muslims. An exception is Sarkar's Swadeshi Movement in Bengal, which discusses Muslim participation in the anticolonial protests in Bengal, even noting that their most gifted orators were Persian instructors (432). For more on Muslim participation in Swadeshi politics, see Sarkar, Swadeshi Movement in Bengal, 424-44.

69. Using sources limited to English and the colonial archive, Rajat Ray attributes Āzād's simultaneously nationalist revolutionary and pan-Islamist ideas to his travels in the Arab Middle East ("Revolutionaries, Pan-Islamists, and Bolsheviks," 104-5). But we know that Āzād was educated in Persian, as well as in Arabic (Douglas et al., Abul Kalam Azad, 21.)

70. Sarkar, Swadeshi Movement in Bengal, 418.

71. Bonakdarian notes Habl al-Matīn's use of colonial administrative and governance structures in India to highlight Iranian governmen- tal need for reform. Like Keddie's characterization of Afghānī, he calls this paradoxical. Such a characterization assumes that the terms of the discussion were absolute, that one could not reject British sovereignty and "culture," while universalizing and embracing a mode of state administration, legal and economic structures dispensed by European colonial powers understood to be systematic and rational (Bonakdarian, “India ix. Relations: Qajar Period”).

72. Sims-Williams, "The Persian Newspaper Habl al-Matin," 1, and Sadr-Hāshimī, Tārīkh-i Jarā'id, 200. Sadr-Hāshimī describes the birth of Qānūn and Habl al-Matīn as the product of the correspondence and coordination that continued between Malkum Khan, Afghānī, and Kāshānī after their meeting. Malkum Khan was a hugely important Persian reformer. See Algar, Mīrzā Malkum Khān. For my engagement with his thought, see Kia, "Moral Refinement and Manhood."
73. Sims-Williams, "The Persian Newspaper," 2-3. Mu'ayyad al-Islam's first reprimand from the colonial government came in 1897 . For more on the life of the newspaper, as well as its editor (including a biography written by Aqa-yi Iranparast, the son of Da'i al-Islam, based on his daughter Fakhr al-Sultan Mu'ayyadzadah's notes [yād-dāsht-hā]), see Sadr-Hāshimī, Tārïkh-i Jarā'id, 2:200-213; the biography is on 205-8.

74. See Rahman, From Consultation to Confrontation, 75, and Bonakdarian, Britain and the Iranian Constitutional Revolution, 155, 233.

75. See Bonakdarian, “India ix. Relations: Qajar Period," 34-44, and Rahman, From Consultation to Confrontation, 242.

76. Rahman, From Consultation to Confrontation, 229, 261.

77. "Taraqqi-yi post-i Hind," Habl al-Matin, no. 11, AH 27 Sha'ban 1314/January 31, 1897, 127. 
Civilized behavior is linked to the refinement that comes from knowledge, here specifically knowledge of modern postal systems. Any people (qawm) can master this knowledge, the article contends, as the daily increasing progress of the Indian postal system attests. Colonial infrastructure is presented as a mobile technology not specifically European, whose implementation in India serves as a model for others, presumably Iran, to emulate.

The newspaper also addressed itself to "the Muslims of India," for instance in an article arguing against alphabet reform and defending the Persian (and, by extension, Urdu) script as integral to the knowledge systems of Muslims. The two authors, at least one of whom designates himself a sayyid in Patna, state that "because of the difficulty of mastering the Arabic language, religious matters, literature $[a d a b]$, poetry, the basis of all the sciences, records, histories ... ethics and other [subjects] necessary for the people of Islam are all in the Persian script and Urdu language, which is derived from the Persian language." 78 Alphabet reform sought to replace the Arabic-based alphabet of Persian and Urdu. The article calls on Indian Muslims to defend this shared script against attackers seeking to do away with it. In doing so, the article emphasizes the close relationship between Urdu and Persian, posing Urdu as a younger relative of Persian..$^{79}$ It would have made little sense to include such a lengthy article defending the use of the Persian script as integral to the Islamic nature of Urdu if the newspaper's primary audience had been Iran or even simply Iranians in British India. Throughout the 189 os, a regular column ti- tled "Mukālamah-yi Sayāh-i İrānı̄ bā Shakhs-i Hind̄̄" ("A Conversation between an Iranian Traveler and an Indian Individual") graced the pages of the lithographed edition. ${ }^{80}$ Once again, the (Muslim) Indian educates his Iranian friend in modern ideas. In spite of the newspaper's diverse implied audience, in this column the Iranian friend is a synecdoche for the Iranian nation. The work of friendship becomes the means to interrogate current ideas and to create, through a transformation of understanding, the conditions by which alternatives can be imagined. In contrast to "traditional epistemology," where two ideas clash and one prevails based on its presumed truth-value, the dialogic form allows for an understanding where knowledge is legitimated through "the turns of stating and questioning, and the synthesizing in consensual agreement." ${ }^{\prime 1}$ The truth-value of the former mode of understanding is predicated on the presumed universality of epistemologies of knowledge, while the dialogic form makes the legitimacy of knowledge contingent on particular contexts. Though in both forms dialectic transformation takes place, and may arrive at the same substantive conclusions, "dialogical hermeneutics undermines the stability of the categories of knowledge by taking away the axis of decision from ideas and entrusting it to the rhetoric of argumentation." ${ }^{\prime 2}$ In the course of a dialogue, competing ideas "coexist, intersect, repel, attract, overlap, and, most importantly, inform each other." ${ }^{33}$ Knowledge produced from such a context emphasizes process over essence, and it can call into question the basic conceptual categories of the
78. "Maktub qabil-i tavajjuh-yi Islamiyan-i Hind," Habl al-Matīn, no. 1, AH 15 Jamadi II 1316/ October 31,1898 , 8. The dates on the top of the actual pages of this article (7-8) vary from those stated on the issue's masthead and are listed as AH 14 Jamadi II 1316/October 30, 1898. The rest of this article continues in the next edition (Habl al-Matin AH 22 Jamadi II 1316/ November 7, 1898, 19-21) and is signed by [first two names obscured] al-Balāgh and Sayyid 'Alī Muhammad Shād, Patna Azimabad.

79. The article references the alphabet reform activism of previous decades by other Persian speakers, such as Ākhūndzādah and Mīrzā Malkum Khan. See Algar, "Malkum Khān," and Kia, “Mirza Fath Ali Akhundzadeh," 429-32.
80. In 1907, Sayyid Hasan Kāshānī, Mu'ayyad al-Islam's younger brother, who was in Tehran publishing the hugely popular daily version of the newspaper, republished selections of this column with moveable type (Mukālamah). Kāshānī had been the paper's agent in Tehran until 1897, when he was expelled by the Iranian government and joined his brother in Calcutta for the next decade. The first edition of the newspaper I have seen dates from October 1898. The column in that edition is numbered the twelfth day, fourth session. The Tehran reprint classifies each column differently so that it is impossible to know from which editions of the weekly paper the reprint draws without access to its earliest editions. In his preface, Kāshānī claims veracity for his Iranian author, whom he identifies as an unnamed traveler of an illustrious family. We are told that in 1894 (which also coincides with the first year of Calcutta's Habl al-Matin) the traveler gathered these treatises (risālah) into volumes and sent them in one of his reports as a novel (rumān), a selection of which were then reproduced in the newspaper (Kāshānī, Mukālamah, 25).

81. Maranhão, "Introduction," 1. Rezaeiyazdi comes to the same conclusion, that Persian dialogues were "the narrative articulation" of the search for "cultural synthesis" ("The Dialogical Tradition of Iranian Modernity," 2).

82. Maranhão, "Introduction," 1.

83. Rezaeiyazdi, "The Dialogical Tradition of Iranian Modernity," 3. 
discussion. ${ }^{84}$ Rezaeiyazdi describes how "the Iranian identity in question becomes an amalgam of ideologies," a "divided subject" that is "articulated through a variety of narrative strategies in the monazereh." 85 In this case, the rhetoric of Persianate friendship is the device by which the column sifts through the terms of modern reform, figured as part of the tradition of ethical association.

The first session begins rather formally, with the Indian greeting the Iranian and asking him basic questions, allowing the Iranian to introduce himself. But through the course of the dialogues, the social frame changes to one of familiarity and friendship. In the twelfth meeting, fourth session, the Iranian begins by saying, " $P$ lease excuse me for not coming to see you these last days, it was because of the severity of the rains." The Indian friend assures him that the rains also kept him at home and that "it is no problem, we have the rest of our lives for further meetings." The social exchanges of mutual solicitude and affection continue for half of a long newspaper column before the Iranian poses his next question about political organizing in the context of what he calls the happiness (suhbat-i shīrinn) of conversation with friends (sukhan-i dust). ${ }^{86}$ The discussions are wide-ranging, covering all manner of topics in one sitting, moving from political activism, to the purpose of modern literature, to trade policy and proper governance.

One of the generic features linking these dialogues to the $a d a b$ literature that conveyed forms of proper conduct is the use of exempla (hikāyatt). Hikāyāt, a ubiquitous feature of ethico-didactic instruction, required interpretive work on the part of the listener/reader; in return they offered the development of individual perception, a necessary feature of moral decision making. ${ }^{87}$ At the end of a long conversation in which the Indian friend has thrown many of the Iranian's ideas into doubt, the Iranian asks his friend what can be done to rectify the situation in Iran. The Indian offers a hikāyat, learned in the course of companionship with one of his (other) friends, to underscore the need for the elites of Iran to cultivate the habit of asking questions in order to overcome their ignorance. It is about a khan who comes from the Persian Gulf coast (garmsir) to take up an official post in (famously cold) Khurasan. ${ }^{88}$ In order to show him favor, the governor bestows on him a lambskin fleece robe, as a robe of honor. The khan is puzzled about how to wear it, but because of his excessive pride and vanity, he is too embarrassed to ask. Instead he goes home and, after seeing how his own lamb's skin was wooly side out, wore his robe (incorrectly) thus. The next time he went to court, he noticed on the way that everyone on the street, in the bazaar, and at the court was laughing. When the governor asked the khan why he was wearing his robe inside out, the khan realized the reason for all the laughter. At this point the Indian interjects with the moral, that "the essential Iranian characteristic, which is the lack of a willingness to make inquiry [mujābiyat], does not allow admitting one's own ignorance."' Resuming the narrative, we are told that in response to the governor, the khan, more desperate to save face than to learn, replies, “"Most high and noble sir, do you know better, or does a lamb?"' The Indian links this story to the Iranian government's continued recalcitrance toward reform, which does not allow even a well-meaning person to point out errors, and will always offer an answer as ridiculous and pathetic as the khan's. ${ }^{89}$ The hikayat is an example of the many ways in which a shared dwelling, a "common background of sociocultural tradition and immediate interests," is both enabled by and further created in the course of these dialogues. ${ }^{90}$ Though the location is in Iran, other features of the story are specific to a shared set of reference points. The location of Khurasan, the custom of bestowing ceremonial robes, and the gift of the hikāyat, given in the companionship of friendship, are all part of a set of imaginaries and practices
84. Maranhão, "Introduction," 1.

85. Rezaeiyazdi, "The Dialogical Tradition of Iranian Modernity," 6. This subject is divided only from the modern perspective of the unified, autonomous self, not from the perspec- tive of earlier Persianate modes of selfhood and belonging.

86. Habl al-Matīn, no. 1, October 31, 1898, 6.

87. Kia, "Adab as Literary Form."
88. Though the term garmsir literally means warm climate, it is an older name for the Gulf coast. See Matthee, Persia in Crisis, 257.

89. Kāshānī, Mukālamah, 58-59. 9o. Maranhão, "Introduction," 5-6. 
harking back to a mutually intelligible Persianate past. ${ }^{91}$ Through this commonality, the Indian friend is able to bring the Iranian to a new level of understanding, so that he realizes the importance of asking questions, creating the conditions of possibility for a new future.

The two friends have different nationalities, which impedes flawless understanding and sets them apart. However, even this separateness permits the reader to gain greater understanding from the dialogue. One exchange begins with the Iranian visiting the Indian's home, where his friend offers him tobacco and tea. In response the Iranian offers the following verse, "Companionship with the beloved is sweeter than a lump of sugar / Keep repeating 'oh dearest one' to my soul; sprinkle it on my desirous palate." ${ }^{92}$ The Indian recoils and asks why the Iranian is reciting these inappropriate love verses to him, a bearded man of fifty-five years with children and grandchildren. The Iranian goes on to explain that he was joking and that he is not a possessor of "that quality [homoerotic desire]." ${ }^{93}$ The Iranian further explains that it is customary to give a verse in answer to kind reception, and that the Indian has misunderstood the meaning of the verse. "The beloved" actually refers to his country, while "dear one" refers to the Indian friend. The Iranian continues to explain that such misunderstandings are the result of the particular mode of Persian instruction in Indian schools, which results in misunderstandings when Indian Persians encounter a native speaker. He concludes by saying how good it is that the Indian has given his attention to, and verified, the meaning of the words, so as to avoid a dispute that would have put them at odds. ${ }^{94}$ Here, the friend literally sprinkles union with homeland on the speaker's tongue; the Iranian can only be a patriot through ethical association with the Indian. Iranians are not the same as Indians, but they both speak Persian, however much variations may sometimes give rise to dissonant understanding. However, through the intercourse of friendship, and through ethical companionship's opportunities for clarification and learning, conflicts can be averted.

The Indian friend has his own lessons to impart about modernity. He informs the Iranian that he has jumped to such unlawful conclusions because "the collections of Iranian poets, which must reflect the mind-set [khiyālāt] of its Iranian people, are full of such [homoerotic] nonsense [khurāfät]." For this reason poetic collections are a brand seared on the national morals, and outsiders (aghyār) have imagined them to be corrupting, such that the administration of India has ordered the censorship of the ribaldry (hazliya $\bar{a}$ ) in such collections, which causes moral corruption of pure young school boys. Indian presses have been ordered not to publish the complete divans of poets like Sa'dī and Qā'ānī without censoring those portions. ${ }^{95}$ Such conversations reflected particular modern sensibilities, derived from dialogue with British Indian colonial contexts. For instance, such sensibilities would result in the exclusion of the hazliyāt that had graced every manuscript of Sa'dī's Kulliyāt (Collected Works) from the fourteenth century, from every printed edition in Iran throughout the twentieth century. ${ }^{96}$ It is the Indian who makes his friend aware of the deleterious effects of certain kinds of ribald poetry that formed the (national) moral character in ways considered antithetical to modernity. This modernity was to be heteronormative but distinguished from its European counterparts by its concomitant homosocial ordering. ${ }^{97}$

The Iranian traveler and his Indian friend
91. On the practice of bestowing ceremonial robes in India, see Gordon, Robes of Honour.

92. Suhbat-i ma'shūq shïrin-tar az qand ast ay 'azīz / hay mukarrar kun ba-jān-i man bakām-i man birīz (Kāshānī, Mukālamah, 45). He later attributes this verse to Mìrzā Habībullah "Qā'ānī" Shirāzī (1808-54), a well-known Qajar poet whose work was lithographed in India, including by Habl al-Matin Press.

93. I have interpreted this as such because the Indian also asks the Iranian why, as a native of Hamdan, he displays Qazvini qualities (a place still stereotyped by the ostensible male homo- erotic propensities of its inhabitants), as well as the references to the beard and age.

94. Kāshānī, Mukalamah, 45-46.

95. Ibid., 46-47.

96. From the fourteenth century, Sa'di's Kulliyāt contained twenty-two sections. The last two sections, mutāyibāt and muzahikāt (jokes and humorous diversions, prose) and khabität (facetiae, verse), are collectively known as the hazliyāt. They are absent from modern editions; see Losensky, "Sa'di." This practice of censoring "obscene" portions of literary works was also the case in India, for instance in Mīr Muhammad Taqī "Mīr"'s Zikr-i Mir, whose latā'if ([bawdy] witticisms) section at the back of the text was removed from the early twentieth-century print version (Mir, Zikr$i$ Mir) and restored in a contemporary translation (Mir, Zikr-i Mir: The Autobiography).

97. Homosociality was made fundamental to the ethical fiber of an Iranian civilization across modernist writing in the late nineteenth century; see Kia, "Moral Refinement and Manhood." On the heteronormative nature of Iranian modernity, see Najmabadi, Women with Mustaches. 
exhibit differences from Ākhūndzādah's princesthe Iranian traveler acquires his information in a more realized India (with its monsoon rains, so appropriate to the location of the newspaper). The Indian friend also uses some Urdu phrases, demonstrating the authorial (and editorial) familiarity with at least the basics of the language. ${ }^{98}$ More interestingly, the two are strangers at the start and become friends in the course of their conversations about modernity. The frame of the nation has now firmly come to be the context through which the individuals are identifiable. No longer are the friends descendants of royal families, from different domains, unified through the lingering intimacy of a shared Persianate heritage. The Iranian traveler tells his friend that upon reaching the age of majority (twenty), he left his birthplace in the city of Hamadan to travel around the various provinces of Iran, which he dubs "my dear homeland [vatan-i 'aziz]." ${ }^{99}$ This is a distinctly nationalist reconceptualization of vatan, which less than a hundred years previously would have referred to Hamadan, not Iran. ${ }^{100}$ The Iranian then describes his subsequent travels to India, Ottoman domains, Russia, Europe, and America. The Indian asks him which country he prefers. The Iranian declares that he prefers Iran, upon which the Indian friend commends him for not forgetting the "love of homeland [hubb al-vatan]" hadith, and he recites a verse that makes the love of homeland a condition of humanity. ${ }^{101}$ Only after establishing this nationalist frame, in which homeland is coterminous with political kingdom, does the Indian ask his Iranian friend about the structure of law and dispensation of justice in Iran. This exchange establishes their shared community, that of men made ethical through particular modes of companionship; these men are distinct from their European counterparts, each of whom loved his country, but also shared other types of affiliations, such as those based on religion and on region.
Conceptualization of reform (islāh) also evinced these broader affiliations. Sayyid Hasan Kāshān̄̄'s 1907 introduction to the reprinted column frames it according to islāh's logic:

It is not hidden from those who have attained the summit of perception that in each era, the perfection of the moral refinement [tahzi $b-i$ $a k h l \bar{a} q]$ of peoples/nations has its own specific demands. . . The most effective of beneficial exhortations are in treatises that disseminate a simple examination of the particulars of truth and make manifest undoubted vices. It explains the pathways of renewal [islāh] and its chief examples with the sweetest words and wittiest meanings and most joyful speech.” (21)

Kāshānī evokes the substance/form complex whereby the most effective content is written in the most beautiful speech (according to the rules of $a d a b$ ), linking ethics and aesthetics as the locus through which reform is envisioned. But this process must be according to languages and ideas specific to each people. Because "every nation has its own special manners and morals ['ādät va $a k h l \bar{a} q]$," their perfection cannot be undertaken with the translated works of others. Every nation that has progressed has done so "in the shade of the thought of its own wise ones" (21-22). He elaborates that though "there is no doubt that novels and stories make the morals and manners of nations upright, but commemoration of the morals and manners of Europeans cannot be very useful for Asians," because "the inhabitants of Asia will never become aware of baseness and beauty from them" (22). It is this acknowledgment of culturally specific means of acquiring modernity that echoes Afghānī. The link between aesthetics and ethics is universal, but the substance and its form are particular to each community. Kāshānī’s nation is not limited to the exclusivist nation-state, Persian speakers, or even Muslims, since he also draws on the distinction between Asians and Europeans. ${ }^{102}$ The country can be interchanged with the region,
98. In their third meeting, the Indian says "bandagì 'arz kartā hūN [I am sorry]." The Tehran reprinted edition includes a parenthetical Persian translation of this phrase. I have not seen the original column to know if this translation was included there. Kāshānī, Mukālamah, 61.

99. Ibid., 27.
100. See Kia, “Accounting for Difference."

101. Kāshānī, Mukālamah, 28.

102. Aydin has noted that ideas of pan-Islamist solidarity emerged at the same time as panAsianism (The Politics of Anti-Westernism, 34). There has been some work on pan-Asian ideas in the context of Calcutta, but always in the context of Bengali-speaking intellectuals whose basis of solidarity with East Asia is Sanskrit-based religions and culture; see, for instance, Frost, “'That Great Ocean of Idealism.'” For a comparison of Iranian and Indian engagement with the example of Japan, see Green, "Shared Infrastructures." 
allowing a parallelism with other Asian countries, in contrast to European countries. These larger regional categories exist simultaneously with nationalist ones, lending similitude between an Indian and Iranian nation as sharing a belonging in Asia. This frames the meaning of a column whose form is a conversation between Muslims, in which the Indian instructs the Iranian based on British Indian models. These institutions and methods of governance are not marked as essentially European, for their growth in colonial India makes them Asian as well, and thus worthy of emulation. Discussion with the beloved Indian friend enacts transformations in perception that allow the Iranian to understand the possibilities of those institutions and methods of governance necessary for separate (though culturally linked) national futures.

Social enactment of the dialogic form resonated for an intellectual milieu that did not view moral perfection as possible in isolation. The fact that dialogue produced knowledge that gained legitimacy through a contextually specific and contingent process-here, the arena of Persianate friendship — raises the issue of uniformity. Do these dialogues work in the same way? The examples examined are quite different, both in the work they try to accomplish and in the degree to which they are dialogic. Ākhūndzādah's dialogue is a masquerade in which universalized European ideals are posited as truths specific to Iran, legitimated through the ethical exchange of traditional Persianate friendship. Afghānī's text wears its dialogue most lightly; for him, the friend exists chiefly to warn against a false friend, the enemy of the cultural edifice within which society is embedded. His text makes the most universalist claims because it defends that very ethico-didactic structure through which moral self-definition, including the practices of friendship, can be understood. Habl alMatīn's dialogue is the most straightforward, seeking to selectively scrutinize (and appropriate) that which has been made universal in a colonial modernity for a modern Iranian self. Because this self still depends on the beloved friend, it is an Iranian self that can recognize the Indian within a common Persianate framework of ethical engagement.
On an extratextual level there is another set of differences, those of location and relationship, both in geographical terms and according to particular sensibilities of belonging. Ākhūndzādah voices his atheistic valorization of pre-Islamic Iran within the Orientalist decline model of history through a prince, one who is Indian but not a foreigner in the nationalist sense. He is the intimate friend, through whose exhortations and wisdom his Iranian counterpart can (re)member their collective ways of being in the world, in order to find the right way forward. This is a purely imagined relationship, built on the lingering memory of a shared Persianate past; Ākhūndzādah lived largely in the Caucasus and never traveled east of Tehran. Afghānī’s figuring of Persianate moral philosophy and political advice through which Islam is essential to culture, and a source of strength, seems to pose a radical contrast. And it does so in terms of substantive content: Ākhūndzādah is precisely the kind of false friend Afghānī warns against, one who poses a threat to a modernized moral structure still built on the edifice of monotheistic eschatology. It is this threat that prompts Afghānī's universalist claims about the binary of materialism and civilization, defending a Muslim culture articulated in Persian terms. Afghānī himself is a traveler to India, and he gives his warning to a Persian Hyderabadi friend. By the end of the century, this Persianate culture becomes the basis for a modern self that is at once Iranian, Muslim, and Asian, allowing for both differentiation from and similitude with India. The column and the story of Habl al-Matīn itself are mirrored reflections of each other that close a circuit around a newly linked Iran and India. The column brings the Iranian reader to India, to make friends, to learn. Meanwhile, with its editor remaining in Calcutta, the paper itself travels back to Iran.

Modes of Indian nationalist imagining, usually attributed to the singularity of colonial modernity, show marked overlaps with Iranian nationalist imagining. Through the end of the nineteenth century, Iranian nationalism was still one in which the spiritual domain contained many explicit similarities with Indians, Asians, and non-Iranian Muslims. ${ }^{103}$ Along with European and Arab Others, perhaps more so, 
the modern Iranian self gained definition through dialogue with Persian friends, some of whom were still Indian, even after the advent of nationalism.

These writers espoused particular, sometimes conflicting visions of being in the world, against or through specific political orderings and religious beliefs. Regardless of such different visions, all use the figure of the friend, ostensibly a personal relationship, to articulate aspirations of ethical collective association. The friend was the crucial figure to take us by the hand and help us see the present anew, creating the conditions by which it would be possible to transform our world according to the ethics of a still shared culture. III!

\section{References}

Abū Tālib Khān, Mīrzā. Masīr-i Tālibī, yā, Safarnāmah-yi Mìrzà Abū Tälib Khān (Journey Seeking Knowledge, or, the Travelogue of Mirza Abu Talib Khan). $4^{\text {th }}$ ed. Edited by Husayn Khadīvjam. Tehran: Shirkat-i Intishārāt-i 'Ilmī va Farhangī, AH 1383/2004-5.

Afary, Janet. The Iranian Constitutional Revolution, I9o6-I9II: Grassroots Democracy, Social Democracy, and the Origins of Feminism. New York: Columbia University Press, 1996.

Afghānī, Jamāl al-Dīn. Haqīqat-i mazhab-i Naychirī va bayān-i hāl-i Naychiriyān (The Truth about the Naychiri School and an Explanation of their State). Bombay: Husayni-yi Jadid, AH 1298/1881.

. "Haqīqat-i mazhab-i Naychirī va Naychīriyān" ("The Truth of the Naychiri School and of Naychiris"). In Maqālāt-i Jamāluddīn Afghānn̄: 'Arab̄̄ maqālāt kā Urdū tarjamah, edited and translated by Sayyid Mubārizuddīn Raf'at, 11-79. Hyderabad: Nafīs Academy, 1946.

- Ibtāl-i tariqah-yi Tabi'‘̀ȳn (Refutation of the Naturist Path). Rasht: Matba'ah-i Sa'ādat, 1910.

. Irshādāt-i Jamāl al-Dīn Afghān̄̄ (The Directives of Jamal al-din Afghani). Edited by Muhammad 'Abd al-Quddus Qāsamī. Lahore: Adārah Furūgh-i Urdū, 1945 .

- Naychirīyah: Haqūqat-i mazhab-i Naychirī va bayān-i hāl-i Naychiriyān (Naychirism: The Truth of the Naychiri School and an Explanation of their State). Tehran: Kitābkhānah-yi Sharq, 1933.

- Naychirīyah, yāa, Nātūriālīsm: Dar radd-i Māddīgarī va Tabi`‘'garī (Naychirism, or, Naturalism: In Rejection of Empiricism and Naturalism). Tabriz: Bungāh-yi Matbū'ātì-yi Dīn va Dānish, 1948.
—. "The Truth about the Neicheri Sect." In Keddie, An Islamic Response to Imperialism, 130-74. Berkeley: University of California Press, 1983.

Ahmad, Aziz. "Sayyid Ahmad Khān, Jamāl al-Dīn alAfghān, and Muslim India.” Studia Islamica 13 (1960): $55^{-78 .}$

Ahmed, Rafiuddin. The Bengal Muslims, I87I-19o6: A Quest for Identity. Delhi: Oxford University Press, 1996.

Ākhundzādah, Fath 'Alī. Maktūbāt-i Mīrzā Fath 'Alì $\bar{A} k h u n d z \bar{a} d a h$. Tehran [?]: Intishārāt-i Mard-i Imrūz, 1985 .

Alam, Muzaffar. Languages of Political Islam: India, I200-1800. Chicago: University of Chicago Press, 2004 .

Algar, Hamid. "Malkum Khān, Ākhūndzada, and the Proposed Reform of the Arabic Alphabet." Middle Eastern Studies 5, no. 2 (1969): 116-3o.

- Mīrzā Malkum Khān: A Study in the History of Iranian Modernism. Berkeley: University of California Press, 1973 .

Arjomand, Said Amir. "Perso-Islamicate Political Ethics in Relation to Sources of Islamic Law." In Mirror for the Muslim Prince: Islam and the Theory of Statecraft, edited by Mehrzad Boroujerdi, 82-106. Syracuse, NY: Syracuse University Press, 2013.

Aydin, Cemil. The Politics of Anti-Westernism in Asia: Visions of World Order in Pan-Islamic and Pan-Asian Thought. New York: Columbia University Press, 2007.

Babayan, Kathryn. Mystics, Monarchs, and Messiahs: Cultural Landscapes of Early Modern Iran. Cambridge, MA: Harvard Center for Middle East Studies, distributed by Harvard University Press, 2002.

Bayat, Mangol. Mysticism and Dissent: Socioreligious Thought in Qajar Iran. Syracuse, NY: Syracuse University Press, 1982.

Beauvoir, Simone de. The Second Sex. Translated by Constance Borde and Sheila Malovany-Chevallier. New York: Vintage, 2011.

Beverley, Eric Lewis. Hyderabad, British India, and the World: Muslim Networks and Minor Sovereignty, c. 1850-1950. Cambridge: Cambridge University Press, 2015.

Bonakdarian, Mansour. Britain and the Iranian Constitutional Revolution of I9o6-I9II: Foreign Policy, Imperialism, and Dissent. Syracuse, NY: Syracuse University Press, 2006.

. "India ix. Relations: Qajar Period, Early Twentieth Century." Encyclopedia Iranica 13, no. 1 (2004): 34-44. Last updated March 27, 2012. www.iranicaonline .org/articles/india-ix-relations-qajar-period-early -2oth-century.
1 
Chatterjee, Partha. The Nation and Its Fragments: Colonial and Postcolonial Histories. Princeton, NJ: Princeton University Press, 1993.

Cole, Juan R. I. “Marking Boundaries, Marking Time: The Iranian Past and the Construction of the Self by Qajar Thinkers." Iranian Studies 29, no. 1-2 (1996): $35^{-5} 5^{6}$.

-. "New Perspectives on Sayyid Jamal al-Din in Egypt." In Iran and Beyond: Essays in Middle Eastern History in Honor of Nikki R. Keddie, edited by Rudolph P. Matthee, Beth Baron, and Nikki R. Keddie, 13-34. Costa Mesa, CA: Mazda, 2000.

Davvānī, Jalāl al-Dīn. Akhlāq-i Jalālī. Edited by 'Abdullāh Ma'sūdī Arānī. Tehran: Intishārāt-i Ittilā'āt, AH 1391/2012-13.

Douglas, Ian Henderson, Gail Minault, and Christian W. Troll. Abul Kalam Azad: An Intellectual and Religious Biography. Delhi: Oxford University Press, 1988.

Frost, Mark Ravinder. "Asia's Maritime Networks and the Colonial Public Sphere, 1840-1920.” New Zealand Journal of Asian Studies 6, no. 2 (2004): 63-94. www .nzasia.org.nz/downloads/NZJAS-Deco4/6_2_5.pdf.

. "“That Great Ocean of Idealism': Calcutta, the Tagore Circle, and the Idea of Asia, 1900-1920." In Indian Ocean Studies: Cultural, Social, and Political Perspectives, edited by Shanti Moorthy and Ashraf Jamal, 251-79. London: Routledge, 2010.

Gandhi, Mahatma. "Hind Swaraj" and Other Writings. Edited by Anthony J. Parel. Cambridge: Cambridge University Press, 2009.

Goldstein, Jan. The Post-Revolutionary Self: Politics and Psyche in France, I750-I850. Cambridge, MA: Harvard University Press, 2005.

Gordon, Stewart, ed. Robes of Honour: Khil'at in Pre-Colonial and Colonial India. New Delhi: Oxford University Press, 2003.

Green, Nile. Bombay Islam: The Religious Economy of the West Indian Ocean, I84O-I9I5. Cambridge: Cambridge University Press, 2011.

"Forgotten Futures: Indian Muslims in the TransIslamic Turn to Japan." Journal of Asian Studies 72, no. 3 (2013): 612. dx.doi.org.ezproxy.cul.columbia .edu/10.1017/Soo21911813000582.

"Shared Infrastructures, Informational Asymmetries: Persians and Indians in Japan, c. 1890-1930." Journal of Global History 8, no. 3 (2013): 414-35.

Gubara, Dahlia E. M. "Beyond Freedom: Reading Labour and Subjectivity in Ottoman Egypt." Paper presented at the Ifriqiyya Trans-African Slaveries Research Network Meeting, Columbia University, New York, May 3-4, 2014 .
Hardy, P. “The 'Oratio Recta' of Baranī’s 'Ta'rīkh-i-Fīrūz Shāhī'-Fact or Fiction?” Bulletin of the School of Oriental and African Studies, University of London 20, no. 1 (1957): $315^{-21 .}$

Hegel, G. W. F. Phenomenology of Spirit. Translated by A. V. Miller. Oxford: Oxford University Press, 1977

Hofmeyr, Isabel. "The Complicating Sea: The Indian Ocean as Method." Comparative Studies of South Asia, Africa and the Middle East 32, no. 3 (2012): 584-9o.

_. "Gandhi's Printing Press: Indian Ocean Print Cultures and Cosmopolitanisms." In South Africa and India: Shaping the Global South, edited by Isabel Hofmeyr and Michelle Williams, 22-37. Johannesburg: Wits University Press, 2011.

Jalal, Ayesha. "Exploding Communalism: The Politics of Muslim Identity in South Asia." In Nationalism, Democracy, and Development: State and Politics in India, edited by Sugata Bose and Ayesha Jalal, 76-103. Delhi: Oxford University Press, 1998.

Kāshānī, Sayyid Hasan. Mukālamah-i sayyāh-i ìrānı̄ bā shakhs-i hindī (A Dialogue between an Iranian Traveler and an Indian Individual). Edited by Ghulām Husayn Mīrzà Sālih. Tehran: Kavīr, AH 1380/2001.

Kashani-Sabet, Firoozeh. Frontier Fictions: Shaping the Iranian Nation, I804-1946. Princeton, NJ: Princeton University Press, 1999.

Kaykāvūs ibn Iskandar ibn Qābūs, 'Unsur al-Ma'ālī. Qābūsnāmah. Edited by Ghulām Husayn Yūsufī. Tehran: Intishārāt-i 'Ilmī va Farhangī, AH 1368/1989-9o.

Keddie, Nikki R. An Islamic Response to Imperialism: Political and Religious Writings of Sayyid Jamāl al-Dīn "al-Afghānī." Berkeley: University of California Press, 1983 .

Kia, Mana. "Accounting for Difference: A Comparative Look at the Autobiographical Travel Narratives of Muhammad 'Ali Hazin Lāhiji and 'Abd al-Karim Kashmiri." Journal of Persianate Studies 2 (2009): 210-36.

"Adab as Literary Form and Social Conduct: Reading the Gulistān in Late Mughal India." In "No Tapping around Philology": A Festschrift in Honor of Wheeler McIntosh Thackston Jr.'s 7oth Birthday, edited by Alireza Korangy and Daniel J. Sheffield, 281-308. Wiesbaden: Harrassowitz, 2014.

. "Moral Refinement and Manhood in Persian." In Civilizing Emotions: Concepts from Europe and Asia, I870-1920, by Margrit Pernau, Helge Jordheim, Orit Bashkin, Christian Bailey, Oleg Benesch, Jan Ifversen, Mana Kia, Rochona Majumdar, Angelika C. Messner, Myoung-kyu Park, Emmanuelle Saada, Mohinder Singh, and Einar Wigen, 146-65. Oxford: Oxford University Press, 2015. 
Kia, Mehrdad. "Mirza Fath Ali Akhundzade and the Call for Modernization of the Islamic World." Middle Eastern Studies 31, no. 3 (1995): 422-48.

. "Pan-Islamism in Late Nineteenth-Century Iran." Middle Eastern Studies 32, no. 1 (1996): 30-52.

Lelyveld, David. Aligarh's First Generation: Muslim Solidarity in British India. Princeton, NJ: Princeton University Press, 1978.

Long, A. G. Conversation and Self-Sufficiency in Plato. Oxford: Oxford University Press, 2013.

Losensky, Paul E. "Sa'di.” Encyclopedia Iranica online. Last modified February 1, 2012. www.iranicaonline.org /articles/sadi-sirazi

Malkum Khān, Mīrzā. "Rafīq va vazīr." In Risalah-hā-yi Mìrzā Malkum Khān Nazìm al-Dawlah (The Treatises of Mirza Malkum Khan Nazim al-Dawlah), edited by Hujjatullāh Asīl, 6o-71. Tehran: Nashr-i Nay, AH 1388/2009-10.

Marāghah'ī, Zayn al-'Ābidīn. Siyāhatnāmah-yi Ibrāhīm Bayk, yā, Balā-yi ta'assub-i $\bar{u}$ : kih yakī az kutub-i pasandīdah bijahat-i imtihānhāa-yi pirūfinshinsī mī bāshad (The Travelogue of Ibrahim Beg). Calcutta: Habl al-Matīn, 1910.

Maranhão, Tullio. "Introduction.” In The Interpretation of Dialogue, edited by Tullio Maranhão, 1-24. Chicago: University of Chicago Press, 1990.

Marashi, Afshin. Nationalizing Iran: Culture, Power, and the State, I870-1940. Seattle: University of Washington Press, 2008.

Marcotte, Roxanne. "Suhrawardi." In The Stanford Encyclopedia of Philosophy, summer 2012 ed., edited by Edward N. Zalta. Last modified April 4, 2012. plato .stanford.edu/archives/sum2012/entries/suhrawardi/.

Martin, Vanessa. Islam and Modernism: The Iranian Revolution of I906. Syracuse, NY: Syracuse University Press, 1989 .

Matthee, Rudi. Persia in Crisis: Safavid Decline and the Fall of Isfahan. London: I. B. Tauris, 2012.

Minault, Gail. The Khilafat Movement: Religious Symbolism and Political Mobilization in India. New York: Columbia University Press, 1982.

Mīr, Muhammad Taqī Mīr. Zikr-i Mir: The Autobiography of the Eighteenth-Century Mughal Poet Mir Muhammad Taqi "Mir.”Translated by C. M. Naim. New Delhi: Oxford University Press, 1999 .

_. Zikr-i Mìr: Ya'nī, Hazrat-i Mīr Taqū Mìr ki khūd nivisht-i savānih 'umrī (Mir's Thoughts: or, the Autobiography of the Events of the Great Mir Taqi Mir's Life). Edited by 'Abd al-Haqq. Awrangabad: Anjuman Taraqqī-yi Urdū, 1928.
Mishra, Pankaj. From the Ruins of Empire: The Intellectuals Who Remade Asia. New York: Farrar, Straus and Giroux, 2012.

Moaddel, Mansoor. Islamic Modernism, Nationalism, and Fundamentalism: Episode and Discourse. Chicago: University of Chicago Press, 2005.

Mottahedeh, Negar. Representing the Unpresentable: Historical Images of National Reform from the Qajars to the Islamic Republic of Iran. Syracuse, NY: Syracuse University Press, 2008.

Mustashār al-Dawlah, Mīrzā Yūsuf Khān. One Word-Yak Kaleme: Nineteenth-Century Persian Treatise Introducing Western Codified Law. Edited and translated by Ali Asghar Seyed-Gohrab and Sen McGilnn. Leiden: Leiden University Press, 2010.

Nabavi, Negin. “Journalism i. Qajar Period.” Encyclopedia Iranica 16, no. 1 (2009): 46-54. Last modified April 17 , 2012. www.iranicaonline.org/articles/journalism -i-qajar-period.

Najmabadi, Afsaneh. Professing Selves: Transsexuality and Same-Sex Desire in Contemporary Iran. Durham, NC: Duke University Press, 2014.

. Women with Mustaches and Men without Beards: Gender and Sexual Anxieties of Iranian Modernity. Berkeley: University of California Press, 2005.

Nikulin, Dmitri. Dialectic and Dialogue. Stanford, CA: Stanford University Press, 2010.

Nizām al-Mulk, Abū 'Alī Hasan ibn 'Alī Tūsī. Siyar alMulūk. Edited by Muhammad Isti'lāmī. Tehran: Zuvvār, AH 1985/2006.

Parvin, Nassereddin. "Habl al-Matin." Encyclopedia Iranica 11, no. 4 (2002): 431-34. Last modified February 24, 2012. www.iranicaonline.org/articles/habl-al-matin.

Pernau, Margrit. “The Virtuous Individual and Social Reform: Debates among North Indian Urdu Speakers." In Civilizing Emotions: Concepts from Europe and Asia, I870-1920, by Margrit Pernau, Helge Jordheim, Orit Bashkin, Christian Bailey, Oleg Benesch, Jan Ifversen, Mana Kia, Rochona Majumdar, Angelika C. Messner, Myoung-kyu Park, Emmanuelle Saada, Mohinder Singh, and Einar Wigen, 169-86. Oxford: Oxford University Press, 2015.

Qā’an̄i Shīrāzī, Habībullāh. Selections from Qā'anī: Recommended for the Degree of Honor Examination in Persian. Edited by Muhammad Kazin Shirazi and D. C. Phillott. Calcutta: Habl al-Matīn, 1907.

Rahman, Matiur. From Consultation to Confrontation: A Study of the Muslim League in British Indian Politics, I906-I9I2. London: Luzac, 1970. 
Ray, Rajat. "Revolutionaries, Pan-Islamists, and Bolsheviks: Maulana Abul Kalam Azad and the Political Underworld in Calcutta, 1905-25." In Communal and Pan-Islamic Trends in Colonial India, rev. ed., edited by Mushirul Hasan, 101-24. New Delhi: Manohar, 1985.

Rezaeiyazdi, Hamid. "The Dialogic Tradition of Iranian Modernity: Monazereh, Simultaneity, and the Making of Modern Iran." Iranian Studies 49, no. 3 (2016): 327-57. doi:10.1080/00210862.2015.1007770.

Sa‘dī Shīrāzī, Shaykh Mushrif al-Dīn. Bāgh-i Urdu: Gulistān-i Sa'dī kā mustanad tarjumah. Translated by Mīr Shīr 'Alī Afsūs. Calcutta: Hindustānī 'chāpekhāna, AH 1217/1802.

Gulistān-i mubtadī. Bombay: Matba'-i Muhammad Maiman, AH 1262/1845-46.

. Gulistān-i mutarjam. Kanpur: Naval Kishore, 1882.

. The Gulistan (Rose Garden) of Sa'di: Bilingual English and Persian Edition. Edited and translated by Wheeler M. Thackston. Bethesda, MD: Ibex Publishers, 2008.

Sadr-Hāshimī, Muhammad. Tārīkh-i jarāìd va majallāt-i Irān. Vol. 2. Isfahan: AH 1327-32/1948-53. Reprinted by Intishārāt-i Kamāl, AH 1363/1984-85.

Said, Edward. Orientalism. New York: Vintage, 1994.

Sanjabi, Maryam B. "Rereading the Enlightenment: Ak-1 hundzada and his Voltaire." Iranian Studies 28, no. 1-2 (1995): 39-6o.

Sarkar, Sumit. The Swadeshi Movement in Bengal, 1903-19o8. New Delhi: People's Publishing House, 1973.

Saudā, Mirzā Muhammad Rafi'. Muntakhab-i masnaviyyāt-i Saudā (Selections from Sauda's Masnavis). Edited by George S. A. Ranking. Calcutta: Habl al-Matīn, 1903.

Sharma, Sunil. "'If There is a Paradise on Earth, It Is Here': Urban Ethnography in Indo-Persian Poetic and Historical Texts." In Forms of Knowledge in Early Modern Asia: Explorations in the Intellectual History of India and Tibet, $1500-I 800$, edited by Sheldon Pollock, 240-56. Durham, NC: Duke University Press, 2011.

Shīrāzī, Husayn 'Alī Tājir. Mìkādūnāmah. Calcutta: Habl al-Matīn, 1907 .

Shuster, W. Morgan. Kitāb-i ikhtināq-i İrān. Calcutta: Habl al-Matīn, 1915 .

Sims-Williams, Ursula. "The Persian Newspaper Habl alMatin." India Office Library and Records: Oriental Manuscripts and Printed Books Newsletter 32 (1983): 1-3.

Tavakoli-Targhi, Mohamad. Refashioning Iran: Orientalism, Occidentalism, and Historiography. London: Palgrave, 2001.

Tūsī, Nāsir al-Dīn. Akhlāq-i Nāsirī. Edited by Mujtaba Mīnuvī and 'Alī Rizā Haydarī. Tehran: Intishārāt-i Khvārazmī, AH 1364/1984-85.
Vahdat, Farzin. God and Juggernaut: Iran's Intellectual Encounter with Modernity. Syracuse, NY: Syracuse University Press, 2002.

Vejdani, Farzin. Making History in Iran: Education, Nationalism, and Print Culture. Stanford, CA: Stanford University Press, 2014.

. "The Place of Islam in Interwar Iranian Nationalist Historiography.” In Rethinking Iranian Nationalism and Modernity, edited by Kamran Scot Aghaie and Afshin Marashi, 205-18. Austin: University of Texas Press, 2014.

Yavari, Neguin. Advice for the Sultan: Prophetic Voices and Secular Politics in Medieval Islam. New York: Oxford University Press, 2014.

Zaydān, Jirjī. Tārīkh-i tamaddun-i islāmī. Calcutta: Habl alMatīn, 1911.

Zia-Ebrahimi, Reza. “'Arab Invasion' and Decline, or the Import of European Racial Thought by Iranian Nationalists." Ethnic and Racial Studies 37, no. 6 (2012): 1043-61. doi: 10.1080/01419870.2012.734389. 